\title{
Don't Start with Europeans First. An Initiative for Extending Voting Rights Should also Promote Access to Citizenship for Third Country Nationals
}

\author{
Hannes Swoboda
}

I am grateful to Philippe Cayla and Catriona Seth for kicking off this debate on the future of EU citizenship and the extension of voting rights in national elections for all EU citizens residing in a second member state.

I believe that the future of EU citizenship, its extension in scope and in nature, is now much more than in the past an essential element of the debate on the future of Europe itself.

The introduction of an EU citizenship - albeit as a complement to nationality of a member state and in a context where nation states remain the main actors - has been an extraordinary symbolic step defining the European Union as a community of values and rights.

The right to vote in local and European elections in the country of residence remains the core of this process, together with the right to move freely across borders. The exercise - albeit imperfect - of these rights has had an enormous symbolic impact on the concept of European identity, leading gradually to the acknowledgement of citizens that moving and residing in a second member state means bringing with you in a big bag almost all the freedoms and rights you enjoy at national level, including the right to participate fully in a community's social, economic and political life.

The whole objective of making the Union an area of freedom, security and justice stems from a dynamic interpretation of the concept of EU citizenship. The now binding Charter of Fundamental Rights embodies the idea that not only EU citizens, but all persons and their rights must be and must remain the core of the European construction.

If persons and their rights have to remain the core of the European construction, then European citizenship must not only be fully exercised but extended in scope. 
In this respect - unrealistic as it may seem in times when the Schengen system has polarised the political discourse and nationality has featured prominently in populist electoral programs - I do think that the necessary evolution of EU citizenship leads to a gradually growing relevance of residence as defining criterion for the exercise of related rights.

For this reason I would support the idea of a citizens' initiative proposing the extension to EU citizens of the right to vote in national elections in the member state of residence. I do not underestimate the complexity of the institutional and constitutional issues that this option would raise, but I am convinced that the initiative would trigger a necessary debate leading possibly to the gradual, temporary, conditional extension of this right in the medium run.

At the same time I do not share the view that we should 'start with the Europeans first'. Although I am convinced that this could have a spill-over effect on the extension of citizenship rights to third country nationals at national level, I believe that EU policy makers should take up the political responsibility to accompany the initiative for the extension of EU citizens' rights with a strong political initiative at EU level encouraging Member states to facilitate access to national citizenship for third country nationals who are long term residents in a member state, gradually leading to uniform approaches and criteria.

I consider it particularly urgent to address the situation of second and third generations of third country nationals, i.e. children and youngsters often born and/or raised in a member state, for whom access to citizenship in that member state is often rendered very complicated or even impossible.

I am perfectly aware that rules governing EU competences differ considerably when we address EU citizenship and the extension of citizenship related rights to third country nationals. However I believe that from a political perspective these two processes have to be closely interlinked, in a possibly virtuous dynamic.

Open Access This chapter is licensed under the terms of the Creative Commons Attribution 4.0 International License (http://creativecommons.org/licenses/by/4.0/), which permits use, sharing, adaptation, distribution and reproduction in any medium or format, as long as you give appropriate credit to the original author(s) and the source, provide a link to the Creative Commons license and indicate if changes were made.

The images or other third party material in this chapter are included in the chapter's Creative Commons license, unless indicated otherwise in a credit line to the material. If material is not included in the chapter's Creative Commons license and your intended use is not permitted by statutory regulation or exceeds the permitted use, you will need to obtain permission directly from the copyright holder. 